\title{
Characterization of the myenteric neuronal population and subpopulation of the duodenum of adult wistar rat fed with hypoproteic chow
}

\author{
DÉBORA M.G. SANT“ANA ${ }^{1}$, EDUARDO J.A. ARAÚJO ${ }^{2}$, DIEGO H. RAMOS ${ }^{1}$, \\ CATCHIA HERMES-ULIANA ${ }^{3}$ and MARIA RAQUEL M. NATALI ${ }^{1}$ \\ ${ }^{1}$ Departamento de Ciências Morfológicas, Universidade Estadual de Maringá, \\ Avenida Colombo, 5790, Zona 07, 08020-900 Maringá, PR, Brasil \\ ${ }^{2}$ Departamento de Histologia, Universidade Estadual de Londrina, \\ Rodovia Celso Garcia Cid, PR 445, Km 380, 86051-980 Londrina, PR, Brasil \\ ${ }^{3}$ Programa de Pós-Graduação em Ciências Farmacêuticas, Universidade Estadual de Maringá, \\ Avenida Colombo, 5790, Zona 07, 08020-900 Maringá, PR, Brasil \\ Manuscript received on August 24, 2010; accepted for publication on May 16, 2011
}

\begin{abstract}
The effects of severe protein malnutrition (4\%) on myenteric neurons of Wistar rat duodenum, in relation to a standard 22\%-protein diet for rodents, were assessed in this study. Segments of the duodenum from 10 rats from each nutritional group were submitted to the elaboration of whole mounts - 5 stained with Giemsa to determine the total population of myenteric neurons and the others stained by a histochemical method to detect nervous cells through the NADPH-diaphorase enzyme activity for studying the subpopulation of nitrergic neurons. The area of 100 neurons per animal, totalizing 2,000 neurons, were randomly measured by using the Image Pro-Plus ${ }^{\circledR}$ software. Malnourished rats presented $34.38 \%$ lower body weight and $10.60 \%$ duodenum length reduction when compared to the control group. Quantitative analysis demonstrated no significant differences between control and malnourished group by using Giemsa; however, as the organ reduction was not followed by an increase inversely proportional to the density of neurons, the condition imposed suggests the loss of neurons from the total population. Nevertheless, through NADPH-d histochemistry, there was a neuronal density increase for the malnourished group. There was no significant difference between the groups for both techniques with respect to the morphometric analysis of the body cell.
\end{abstract}

Key words: enteric nervous system, malnutrition, myenteric plexus, nitrergic neurons.

\section{INTRODUCTION}

Malnourishment is predominant in several developing countries, especially among children under unfavorable socioeconomic conditions. Improper food intake, parasitary infections, poor hygiene conditions, low educational levels and income are some of the major causes of such scenario (Souza et al. 2006).

Correspondence to: Débora de Mello Gonçales Sant'Ana

E-mail:dmgsantana@gmail.com
The effects of malnutrition on the myenteric plexus have been assessed by a number of authors in studies on the total neuronal population (Fiorini et al. 1999, Natali et al. 2003, Sant'Ana et al. 2006, Hermes et al. 2008) and nitrergic subpopulation (Sant'Ana et al. 2001, Araújo et al. 2003, 2006, Moreira et al. 2008). However, there are a few studies relating the lack of protein of two major myenteric neuronal subpopulations: nitrergic and cholinergic (Cowen et al. 2000). 
The total myenteric population is constituted by two subpopulations: the nitrergic neurons, which use nitric oxide (NO) synthesized through nitric oxide synthase (NOS), and the cholinergic neurons, which use acetylcholine synthesized through choline acetyltransferase (ChAT) (Phillips et al. 2003). Thus, by using the pan-neuronal markers, it is possible to determine the total population and NADPHdiaphorase has demonstrated to be a reliable marker for nitrergic myenteric neurons (Dawson et al. 1991). Therefore, the total population subtracted from the nitrergic neurons results in estimated values of cholinergic neurons as the marking of cholinergic neurons presents a number of complications (Chiocchetti et al. 2003).

Based on what has been mentioned so far, there is a gap with respect to the effects of protein lack on the neuronal phenotypic constitution of the myenteric plexus. Therefore, this study had the purpose of assessing the total neuronal population and subpopulations (nitrergic and cholinergic) with respect to morphometric and quantitative aspects of myenteric plexus neurons in Wistar rat duodenum submitted to prolonged protein malnutrition.

\section{MATERIALS AND METHODS}

All the procedures involving the use of animals are in accordance with the ethical principles adopted by Colégio Brasileiro de Experimentação Animal and were approved by the UNIPAR Research Ethics Committee.

\section{ACQUIRING THE GROUPS}

Twenty adult, male, 90-day-old, healthy, withoutapparent-malformation, $\pm 298.7 \mathrm{~g}$ Wistar rats were used. They were assigned into two groups as follows: a) Ten animals were fed a standard 22\%-protein rat chow - NUVILAB ${ }^{\odot}$ (recommended by the National Research Council \& National Health Institute - USA) - and water ad libitum for 90 days, b) Ten animals were fed a hypoproteic diet- $4 \%$ protein level, from the addition of corn amid to the NUVILAB $^{\odot}$ chow (Araújo et al. 2005) and water ad libitum. All animals were kept in individual cages under constant temperature, $12 \mathrm{~h}$ dark/bright alternate illumination cycles for 90 days. The animals were weighed and anesthesized at their $180^{\text {th }}$ day of age with: Acepran $(1.26 \mathrm{~mL} / \mathrm{kg})+$ Ketamine $10 \%(1.26 \mathrm{~mL} / \mathrm{kg})+$ Xylazine $2 \%(0.42 \mathrm{~mL} / \mathrm{kg})+$ Atropine $1 \%(0.22 \mathrm{~mL} / \mathrm{kg})$, intramuscularly (Pachaly et al. 2003). Laparotomy was conducted and the duodenum removed by having the pylorus and the duodenal-jejunal flexure as anatomical limits.

\section{Whole-Mounts PREPARATIONS}

Five animals from each group had their duodenum washed in a $0.9 \%$ saline solution, filled and immersed in formol-acetic fixing solution for $48 \mathrm{~h}$. They were then dissected and stained with Giemsa (Methylene blue) in Sorensen's phosphate buffer (Barbosa 1978).

The remaining intestinal segments from each group were submitted to NADPH-diaphorase histochemistry. They were washed and filled with phosphate buffer ( $\mathrm{pH}$ 7.4), fixed with 4\% paraformaldehyde (Merck, Darmstad, Germany) in a $0.1 \mathrm{M}$ phosphate buffer $(\mathrm{pH} 7.4)$ for $30 \mathrm{~min}$, immersed in $0.3 \%$ Triton $\mathrm{X}-100$ in $0.01 \mathrm{M}$ PBS(pH 7.4), then washed 10 times (10 min each) in PBS and submersed during $60 \mathrm{~min}$ in an incubation medium containing, for each $100 \mathrm{~mL}$ : $25 \mathrm{mg}$ NBT (Sigma, Steinheim, Germany); $50 \mathrm{mg}$ of $\beta$-NADPH (Sigma, Steinheim, Germany); $0.3 \mathrm{~mL}$ of Triton X-100 and $0.1 \mathrm{M}$ (pH 6.0) tris-HCl buffer (GibcoBRIL, New York, USA). After ncubation and being washed three times in PBS (5min each), the segments were opened and immersed in a $4 \%$ paraformaldehyde solution (Scherer-Singler et al. 1983).

\section{NeURONAL Quantitative ANALYsis}

For the quantification of myenteric neurons, counting was conducted by sampling with a $40 \mathrm{X}$ objective coupled to a light microscope. Forty 
microscopic fields on the antimesenteric region and forty microscopic fields on the intermediate region of the intestinal circumpherence were examined in 5 animals from each nutritional group for each technique. The microscopic field area was $0.22 \mathrm{~mm}^{2}$, totalizing $17.6 \mathrm{~mm}^{2}$.

All neurons from each microscopic field were counted by considering the half neurons from one field and discarding the ones from the other.

The estimated amount of cholinergic neurons was determined by reducing the mean of neurons evidenced by the NADPH-d of the total population stained with Giemsa, according to Phillips et al. (2003).

\section{Determining THe CELl Body AREA}

Randomly, the cell body area (profile) of 100 neurons per animal was measured, totalizing 2,000 neurons. This analysis was conducted by using Image-Pro Plus 4.5 (Media Cybernetics, Silver Spring, MD, EUA) - images acquired from a high resolution camera (Q Color 3 Olympus American INC - Canada) coupled to an Olympus BX 41 microscope and the software Q Capture Pro 5.1.

\section{STATISTICAL ANALYSIS}

The data obtained were submitted to Student's $\mathrm{t}$-Test for the comparison between the groups at the 5\% significance level.

\section{RESULTS}

\section{EXPERIMENTAL MODEL}

Experimental data (4\% of protein in the chow) allowed noticing the establishment of a lack-of-protein condition in adult Wistar rats. The animals presented cutaneous irritation, fur loss, weight loss and diarrhea.

At the end of the experiment, there was significant reduction $(p<0.05)$ of the body weight of the animals from the malnourished group $(196.08 \pm 31.65 \mathrm{~g})$ in relation to the control group $(361.78 \pm 30.95 \mathrm{~g})$. The length of the duodenum for the malnourished group $(6.66 \pm 0.73 \mathrm{~cm})$ presented significant reduction $(\mathrm{p}<0.05)$ when compared to the control group $(7.45 \pm 0.91 \mathrm{~cm})$.

\section{GANGLION MORPHOLOGY}

Despite the technique used, we verified that the different nutritional groups maintained the standard for typical ganglion organization. The ganglions from the myenteric plexus located among the circular and longitudinal extracts of the external muscle were polygonal, triangular and angular with different sizes.

\section{NEURONAL MORPHOMETRY AND DENSITY}

Results with respect to neuronal quantification and morphometry of the cell body are presented in Tables I, II and Figure 1. Regardless the nutritional group, we verified higher neuronal population for the whole mounts stained with Giemsa when compared which the preparations stained with NADPH-diaphorase histochemistry.

There was no difference between the groups ( $p>0.05$ ) when comparing the total population from the control and malnourished group with respect to neuronal density and area of cell body. However, higher neuronal density $(p<0.05)$ was noticed for the nitrergic population in the malnourished group, with maintenance of the cell body. The estimated amount of cholinergic neurons presented no significant difference while comparing control and malnourished group.

\section{DISCUSSION}

The protein malnutrition model used in the present study was appropriate as the animals from the malnourished group presented weight loss, fur loss, diarrhea and duodenum length reduction throughout the experiment, what confirms its efficacy.

The $4 \%$ protein level in the rat chow was insufficient to enable the evolution of weight. Animals from the control group presented $21.15 \%$ 


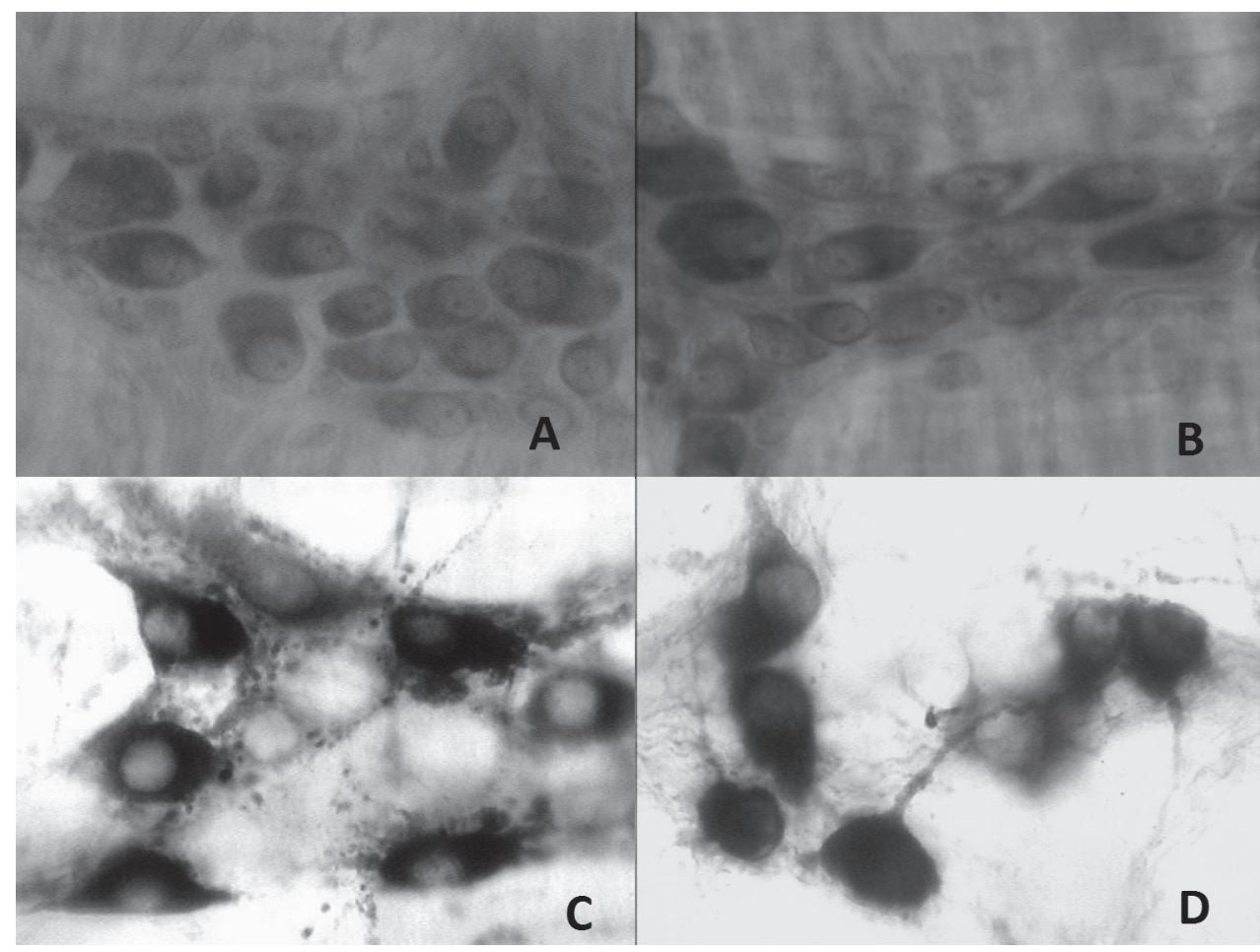

Figure 1 - Duodenal whole mounts evidencing myenteric plexus ganglions: Giemsa. A) Control Group; B) Malnourished Group. NADPH-diaphorase histochemistry; C) Control Group; D) Malnourished Group. 400x.

TABLE I

Mean \pm standard deviation of the amount of myenteric plexus neurons of the duodenum evidenced by Giemsa and NADPH-diaphorase on the animals from the control and malnourished groups $(n=10$ /group).

\begin{tabular}{cccc}
\hline Technique & Intestinal Region & Control Group & Malnourished Group \\
\hline GIEMSA & Intermediate & $115.0 \pm 18.3$ & $119.86 \pm 10.8$ \\
$\left(\mathrm{~mm}^{2}\right)$ & Antimesenteric & $106.2 \pm 9.63$ & $99.15 \pm 5.78$ \\
& Total & $221.3 \pm 25.8$ & $219.0 \pm 15.4$ \\
NADPH-d & Intermediate & $30.25 \pm 4.63$ & $33.72 \pm 2.13$ \\
$\left(\mathrm{~mm}^{2}\right)$ & Antimesenteric & $24.3 \pm 4.94$ & $28.19 \pm 1.87$ \\
& Total & $53.95 \pm 4.2 *$ & $61.9 \pm 2.92^{*}$ \\
Estimated Cholinergic & Intermediate & $84.75 \pm 16.32$ & $86.14 \pm 13.06$ \\
Neurons $\left(\mathrm{mm}^{2}\right)$ & Antimesenteric & $81.90 \pm 10.14$ & $70.94 \pm 7.32$ \\
& Total & $167.35 \pm 26.14$ & $157.10 \pm 18.16$ \\
\hline
\end{tabular}

* Indicates significance between the groups; Student's t-Test $\mathrm{p}<0.05$. 
TABLE II

Mean \pm standard deviation of the area of the cell body of the myenteric plexus neurons of the duodenum evidenced by Giemsa and NADPH-diaphorase of the animals of control and malnourished groups $(\mathrm{n}=10 / \mathrm{group})$.

\begin{tabular}{cccc}
\hline Technique & Intestinal Region & Control Group & Malnourished Group \\
\hline GIEMSA & Intermediate & $159.0 \pm 47.0$ & $139.2 \pm 35.2$ \\
$\left(\mathrm{~mm}^{2}\right)$ & Antimesenteric & $150.9 \pm 38.4$ & $128.3 \pm 33.1$ \\
& Total & $155.0 \pm 43.3$ & $134.0 \pm 34.6$ \\
NADPH-d & Intermediate & $161.0 \pm 86.0$ & $187.4 \pm 47.1$ \\
$\left(\mathrm{~mm}^{2}\right)$ & Antimesenteric & $166.0 \pm 47.0$ & $149.5 \pm 41.7$ \\
& Total & $163.38 \pm 69.6$ & $168.4 \pm 48.3$ \\
\hline
\end{tabular}

weight gain, on the other hand, the ones receiving $4 \%$ protein not only presented no weight gain but also had their body weight reduced $34.38 \% 12$ weeks after treatment. Other studies using rats reported delayed weight gain in animals fed with hypoproteic diet containing several levels of protein (Natali and Miranda-Neto 1996, Brandão et al. 2003, Natali et al. 2000, 2003). It is believed that the body weight reduction is probably due to the lower development of fat and lean mass in these animals which can represent an adaptation mechanism against low food availability in order to preserve the nervous tissue (Araújo et al. 2006).

The use of membrane preparations was chosen for the quantitative and morphometric analysis of the myenteric plexus neurons. It is a highly applied method for studying intramural plexi as it ensures a broader and safer analysis of what was collected from a histological section (Gabella 1979, Natali and Miranda-Neto 1996, Araújo et al. 2006, Natali et al. 2005). We also chose to carry out the quantifications and measurements by considering the regionalization of the intestinal circumpherence (Sant'Ana et al. 1997) granting more homogeneity to the sample.

The Giemsa method (based on the affinity of the pigment to the acid organelles of the cytoplasm) enables the estimation of the total neuronal population in spite of the nutritional group. NADPH-diaphorase histochemistry enables evidencing a nitrergic neuron subpopulation which is usually numerically smaller than that evidenced by pan-neuronal markers (Santer 1994, Jonhson et al. 1998).

When comparing the total population of the control group with the malnourished group, in terms of neuronal density, no difference was found between the groups $(\mathrm{p}>0.05)$. While assessing the population density in experimental models with malnutrition, it is extremely important to analyze the size of the studied organ as these models imply in a deficit concerning the size of the intestine making the neurons more concentrated (Miranda-Neto et al. 1999, Natali et al. 2003, Araújo et al. 2006). Since there was no significant difference between the groups with respect to the total population in none of the regions analyzed, it is suggested that there was a loss of these neurons (around 9.60\%), as the duodenum presented length $10.60 \%$ shorter for the malnourished group and, thus, the neuronal population was expected to be concentrated within the same proportion. Thus, it was expected that the neurons from the malnourished group were in larger number when compared to the control group - what was noticed only for the population evidenced by NADPH-d. These data confirm the hypothesis proposed by Cowen et al. (2000) in which the cholinergic neurons are more vulnerable to the effects of malnutrition. The nitrergic population presented an amount larger than the 
malnourished group, what led us to infer that the nitrergic subpopulation is more resistant to injuries even under unfavorable conditions, it lost less neurons than the normofed group.

Studies involving animals receiving $8 \%$-protein chow have demonstrated maintenance of the total population toward malnutrition (Torrejais et al. 1995, Fiorini et al. 1999, Miranda-Neto et al. 1999, Natali et al. 2003), thus showing that the $4 \%$-protein level causes more severe alterations to rat myenteric neurons. Through NADPH-diaphorase, we noticed an increase of the neurons expressing the nitric oxide synthase (NOS) (around 2.20\%) for the animals fed with a lack-of-protein diet. Similar result was noticed on the ileum where a 9.2\% increase of positive NADPH-d neurons occurred for the animals receiving 4\% protein (Moreira et al. 2008), demonstrating that these neurons are less vulnerable to cell death (Cowen et al. 2000). However, a study with $8 \%$ protein demonstrated the occurrence of no alteration on the neuronal density of rat duodenum through NADPH-d histochemistry (Mello et al. 2004). Others verified significant reduction on the amount of myenteric neurons from rats receiving hypoproteic diet in the large intestine (Araújo et al. 2003, 2006), what may imply that the difference may be related to a number of factors uch as the type o malnutrition applied by different authors, age and life period of the animal as well region of the gut.

When we compared our findings with those from other intestinal segments from the same experimental animals, we verified that there is no alteration with respect to the total population for both large and small intestines, but increase of the positive-NADPH-d myenteric neurons in the small intestine (Moreira et al. 2008) as well as their decrease in the large intestine (Araújo et al. 2006), what demonstrated that large intestine suffer more injuries resulting in diarrhea for the decrease of nitrergic neurons and increase of cholinergic neurons responsible for intestinal contraction.
Acetylcholine is one of the most important neurotransmitters of the Enteric Nervous System (ENS) found in excitatory motor neurons (Freytaga et al. 2008). The estimated cholinergic subpopulation was predominant in our study representing approximately $76 \%$ in the control group and $72 \%$ in the malnourished group. This finding was also noticed for small intestine which presented $60 \%$ of cholinergic neurons (Sang and Young 1996). The estimated number of cholinergic was $6.1 \%$ smaller for the malnourished group with a possible eduction of approximately $4.5 \%$ of negative NADPH-d neurons (cholinergic).

The effects of malnutrition did not affect the cell body area of the myenteric neurons in both techniques assessed. In a study on malnutrition with $8 \%$ protein, Mello et al. (2004) did not notice any alterations on the profile of positive NADPH-d neurons, suggesting that they are less susceptible to morphological alterations.

Natali et al. (2003), in a study on the duodenum of animals receiving a $8 \%$-protein diet, found a decrease for the profile of the cell body of the total population of myenteric neurons -result not noticed in this study. It could be inferred that the reduction of the protein level to $4 \%$ may have caused more severe alterations as the neurons reduced their size and activity until death.

Thus, it was conclude that a $4 \%$-protein diet did not lead to cell body alteration, however, there was neuronal loss for the total population and cholinergic subpopulation, with the increase of density of nitrergic neurons.

\section{ACKNOWLEDGMENTS}

The authors thank Universidade Paranaense (UNIPAR) for the financial support.

\section{RESUMO}

Objetivou-se avaliar os efeitos da desnutrição protéica severa (4\%) sobre os neurônios mientéricos do duodeno de ratos Wistar, comparando-se a uma dieta padrão para 
roedores de $22 \%$ de proteína. Para este estudo, segmentos do duodeno de 10 ratos de cada grupo nutricional foram submetidos à elaboração de preparados de membrana, sendo cinco corados pelo método de Giemsa, para estimar a população mientérica total e os demais corados pelo método histoquímico de evidenciação de células nervosas, por meio da atividade da enzima NADPHdiaforase para estudo da subpopulação de neurônios nitrérgicos. Aleatoriamente, foram mensuradas as áreas de 100 neurônios por animal, perfazendo um total de 2.000 neurônios, que foram mensurados através de um Sistema de Análise de Imagens Computadorizada - Image ProPlus ${ }^{\circledR}$. Os ratos desnutridos apresentaram peso orporal $34,38 \%$ menor e uma redução no comprimento do duodeno de $10,60 \%$ quando comparado ao grupo controle. A análise quantitativa demonstrou não haver diferença significativa na comparação entre os grupos controle e desnutrido para técnica de Giemsa, porém como a redução do órgão não foi acompanhada por um aumento inversamente proporcional na densidade de neurônios, sugere-se que a condição imposta causou perda de neurônios na população total. Entretanto com a histoquímica da NADPH-d houve um umento da densidade neuronal no grupo desnutrido. $\mathrm{Na}$ análise morfométrica do perfil celular neuronal não houve diferença significativa entre os grupos em ambas as técnicas evidenciadas.

Palavras-chave: sistema nervoso entérico, desnutrição, plexo mioentérico, neurônios nitrérgicos.

\section{REFERENCES}

ARAÚJo EJA, SANT'ANA DMG, Molinari SL AND MirandANeto MH. 2005. Biometric and food consumption parameters of rats subjected to hypoproteic and hipercaloric diet. Arq Cienc Vet Zool Unipar 8: 131-138.

ARAúJo EJA, SANT'ANA DMG, MOLINARI SL AND MIRANDANeTO MH. 2003. Effect of protein and vitamin B deficiency on the morpho-quantitative aspects of the myenteric plexus of the descending colon of adult rats. Arq Neuropsiquiatr 61: 226-233.

AraúJo EJA, SANT'ANA DMG, MOLINARI SL AND MIRANDANeTO MH. 2006. Quantitative study of the myenteric plexus of the descending colon of young rats subjected to sintese protein deficiency. Int J Morphol 24: 591-597.

BARBOSA AJA. 1978. Técnica histológica para gânglios intramurais em preparados espessos. Rev Bras Pesq Med Biol 11: 95-97.
BRANDÃo MCS, ANGElis RC, SOUZA RR, FróES LB AND LIBERTI EA. 2003. Effects of pre- and postnatal protein energy deprivation on the myenteric plexus of the small intestine: a morphometric study in weanling rats. Nutr Res Estados Unidos 75: 07-15.

Chiocchetti R, Poole DP, Kimura H, Aimi Y, Robbins HL, CAstelucci P AND Furness JB. 2003. Evidence that two forms of choline acetyltrasferase are differentially expressed in subclasses of enteric neurons. Cell Tissue Res 311: 11-22.

Cowen T, Johnson J, Soubeyre V And SAnter RM. 2000. Restricted diet rescues rat enteric motor neurones from age related cell death. Gut 47: 653-660.

DAWSON TM, BREDT DS, FoTUHI M, HWANG PM AND SNYDER SH. 1991. Nitric oxide synthase and neuronal NADPH diaphorase are identical in brain and peripheral tissues. Neurobiol 88: 7797-7801.

Fiorini A, Molinari SL, NATALI MRM AND MirANDA-Neto MH. 1999. Quantitative morphological analysis of the myenteric neurons of the ileum in rats under experimental desnutrition. Acta Scientiarum 21: 404-423.

Freytag C, Seeger J, Siegemund T, Grosche J, Grosche A, Freeman DE, Schusser GF and Hartig W. 2008. Immunohistochemical characterization and quantitative analysis of neurons in the myenteric plexus of the equine intestine. Brain Res 1244: 53-64.

GABELLA G. 1979. Innervation of the gastrointestinal tract. Int Rev Citol 59: 129-191.

Hermes C, Almeida EC, Souza EA, Araújo EJA AND SANT'ANA DMG. 2008. Efeitos da desnutrição protéica severa sobre aspectos morfológicos e quantitativos dos neurônios mientéricos do cólon ascendente de ratos. Arq Cienc Vet Zool Unipar 11: 13-16.

JOHNSON RJR, SCHERMAN M, SANTER RM AND COWEN T. 1998. The effects of age of the overall population and on sub-populations of myenteric neurons in the rat small intestine. J Anat 192: 479-488.

Mello ST, LiBerti EA, SANT'ANA DMG, MolinARI SL AND MirANDA-NeTO MH. 2004. Estudo morfoquantitativo do plexo mioentérico do duodeno de ratos submetidos a carência de proteínas e vitaminas do complexo B. Acta Scientiarum Biological Sciences 26: 251-256.

Miranda-Neto MH, Molinari SL, Stabile SR, SANT'AnA DMG AND NATALI MRM. 1999. Morphological and quantitative study of the myenteric neurons of the jejunum of malnourished rats (Rattus norvegicus). Arq Neuropsiquiatr 57: 387-391.

Moreira N, Hermes C, Almeida EC, SANT'AnA DMG AND ARAÚJO EJA. 2008. Quantitative analysis of the neurons from the myenteric plexus in the ileum of rats submitted to severe protein deficiency. Arq Neuropsiquiatr 66: 242-245.

NATALI MRM AND MiRANDA-NETO MH. 1996. Effect of maternal proteic undernutrition on the neurons of the myenteric plexus of duodenum of rats. Arq Neuropsiquiatr 54: 273-279.

NATALI MRM, MiRANDA-Neto MH AND ORSI AM. 2000. Effect of hypoproteic diet supply on adult Wistar on adult rats (Rattus Norvegicus). Acta Scientarum 22: 567-571. 
NATALI MRM, MiRANDA-Neto MH AND ORSi AM. 2003. Morphometry and quantification of the myenteric neurons of the duodenum of adult rats fed with hypoproteic chow. Int J Morphol 21: 273-277.

NATALI MRM, MOLINARI SL, VALENTINI LC AND MIRANDANeTO MH. 2005. Morphoquantitative evaluation of the duodenal myenteric neuronal population in rats fed with hypoproteic ration. Biocell 29: 39-46.

PACHALY JR, SANT’ANA DMG, ARAúJo EJA, CIFFONI EMG AND ACCO A. 2003. Anestesia of Wistar rats (Rattus norvegicus) with allometrically scaled dose of Ketamine, Xylazine, Acepromazine and Atropine - preliminary report. Arq Cienc Vet Zool UNIPAR 6: 195-195.

Phillips RJ, KiefFer EJ AND Powley TL. 2003. Aging of the myenteric plexus: neuronal loss is specific to cholinergic neurons. Auton Neurosci 106: 69-83.

SANG Q AND Young HM. 1996. Chemical coding of neurons in the myenteric plexus and external muscle of the small and large intestine of the mouse. Cell Tissue Res 284: 39-53.

SANT'ANA DMG, MiRANDA-Neto MH, SOUZA RR AND MOLINARI SL. 1997. Morphological and quantitative study of the myenteric plexus of the ascending colon of rats subjected to proteic desnutrition. Arq Neuropsiquiatr 55: 687-695.
SANT'ANA DMG, MOLINARI SL, ARAÚJO EJA AND MIRANDANeTO MH. 2006. The effect of both protein and vitamin B complex deficiency on the morphoquantitative features of the myenteric plexus of the ascending colon of adult rats. Arq Cienc Vet Zool UNIPAR 9: 135-140.

SANT'ANA DMG, Molinari SL AND Miranda-Neto MH. 2001. Effects of protein and vitamin B deficiency on blood parameters and myenteric neurons of the colon of rats. Arq Neuropsiquiatr 59: 493-498.

SANTER RM. 1994. Survival of the population of NADPHdiaforase stained myenteric neurons in the small intestine of aged rats. J Auton Nerv Syst 49: 115-121.

SCHERER-Singler U, VicENT SR, KiMURA H AND MCGEER EG. 1983. Demonstration of a unique population of neurons with NADPH-diaphorase histochemistry. J Neurosci Methods 9: 229-234.

Souza JC, Mauro AK, Carvalho HA, Monteiro MRP AND MARTINO HSD. 2006. Qualidade protéica de multimisturas distribuídas em Alfenas. Rev Nutr 19: 685- 692.

TORREJAIS MM, NATALI MRM, CONEGERO CI AND MIRANDANETO MH. 1995. Effects of proteic malnutrition after breast-feeding on the morphology if the intestinal wall and myenteric neurons of the ileum of rats. Rev Unimar $17: 315-327$ 